\title{
Negative effects of sediment deposition on grazing activity and survival of the limpet Patella vulgata
}

\author{
Laura Airoldi ${ }^{1, *}$, Stephen J. Hawkins ${ }^{2,3}$ \\ ${ }^{1}$ Dipartimento di Biologia Evoluzionistica Sperimentale and Centro Interdipartimentale di Ricerca per le Scienze Ambientali \\ in Ravenna, University of Bologna, Via S. Alberto 163, 48100 Ravenna, Italy \\ ${ }^{2}$ Marine Biological Association of the UK, The Laboratory, Citadel Hill, Plymouth PL1 2PB, UK \\ ${ }^{3}$ School of Biological Sciences, University of Plymouth, Drake Circus, Plymouth PL4 8AA, UK
}

\begin{abstract}
Sediments are likely to influence the distribution of limpets and dominant sessile species on intertidal rocky shores by smothering and interfering with feeding activity. This hypothesis was tested by field observations and laboratory experiments in which the effects of different amounts and grain sizes of sediments on the grazing and survival of the limpet Patella vulgata L. were measured. On rocky shores close to Plymouth (south-west UK), natural patchiness of sediment deposits was related to the distribution of $P$. vulgata and macroalgae. Sediments severely impaired $P$. vulgata. Even a $\sim 1 \mathrm{~mm}$ thick layer of sediment (equivalent to $50 \mathrm{mg} \mathrm{cm}^{-2}$ ) decreased grazing activity by $35 \%$, with total inhibition and mortality at loads of $200 \mathrm{mg} \mathrm{cm}^{-2}$ of fine sediments. Coarse sediments had less severe effects than fine sediments.
\end{abstract}

KEY WORDS: Sedimentation · Grazing $\cdot$ Patella vulgata $\cdot$ Grain size $\cdot$ Rocky shores

\section{INTRODUCTION}

The nature and amount of sediment that occurs on rocky shores either naturally or as a consequence of human activities is highly variable, resulting in a variety of possible effects on biota. Recent experiments have made substantial progress in detecting the effects of sedimentation on rocky coast assemblages (reviewed by Airoldi 2003), but our ability to generalise these effects is restricted.

Herbivorous organisms, including limpets, are often scarce in areas with high sediment loading (Airoldi \& Virgilio 1998, Airoldi 2003, Pulfrich et al. 2003, Schiel et al. 2006). This effect of sediment is particularly important because grazing is a key process controlling algal vegetation on rocky shores (Southward 1964, Lubchenco \& Gaines 1981, Hawkins \& Hartnoll 1983, Benedetti-Cecchi et al. 2001). Direct evidence of the negative effects of sediments on limpets is limited.
Following the flooding of the Orange River in South Africa, different assemblages developed in areas most affected by water dilution and high loads of sediments, and the shore changed from being dominated by patellid limpets to being dominated by ephemeral algae (Branch et al. 1990). Experiments in which limpets were transplanted to areas buried or not buried by shifting sands (Robles 1982), or in which they were exposed to burial conditions in the laboratory (Marshall \& McQuaid 1989), showed that some species of limpets suffer mortality under severe burial by sand. However, there has been no research designed to identify sub-lethal effects arising from less extreme but possibly frequent sedimentation events, and eventual critical levels of perturbation by sediment are not known.

The limpet Patella vulgata L. forms high-density populations on rocky intertidal shores along the coasts of north-west Europe (Hawkins et al. 1992). This 
limpet is an important macroalgae grazer, controlling the abundance and distribution of macroalgae (Southward 1964, Hawkins 1981, Jenkins et al. 2005). Circumstantial observations suggest that this species may be affected negatively by sediment, because its density tends to decline with shelter (presumably associated with an increase in sediment), and its grazing activity is limited by the presence of turf-forming algae that typically trap sediment (Jenkins et al. 1999). The biology and ecology of $P$. vulgata have been studied extensively, but little is known about its responses to different amounts and types of sediments. We analyzed the relationships between the distribution of sediments, $P$. vulgata and dominant sessile species on rocky shores in the south-west UK, and tested the hypothesis that sediments negatively affect the grazing rate and survival of $P$. vulgata in the laboratory. Responses of $P$. vulgata to different amounts and grain sizes of sediments were quantified, with the aim of identifying the critical levels above which detrimental effects of sediments become manifest.

\section{MATERIALS AND METHODS}

Field observations. Field observations were made in April and May 2002 at 4 moderately exposed rocky platforms (Looe, Cawsand Bay, Heybrook Bay and Wembury) and a sheltered one (Cremyll) in the south of Devon, UK. One mid-shore site $\left(\sim 20 \mathrm{~m}^{2}\right)$ with patchy distribution of sediments was selected on each shore with the exception of Wembury, where 2 sites about $500 \mathrm{~m}$ apart were selected. At each of these 6 sites, cover $(\%)$ of sessile species and sediment (both on rock and entrapped in turfs) and number of limpets, mainly represented by Patella vulgata, were estimated visually in 10 replicate $20 \times 20 \mathrm{~cm}$ plots.

The relationships between the patchy accumulations of sediment and the distribution of species were examined by superimposing the cover values of sediments onto a non-metric multi-dimensional scaling (MDS) ordination of benthic species (Clarke 1993). The MDS was based on Bray-Curtis dissimilarities from a matrix of 4 th root-transformed abundances of 11 species. The correlation between abundance of Patella vulgata and sediment was also calculated.

Laboratory experiments. Experiments were run using a tidal tank system with direct daylight illumination, running seawater and a semidiurnal cycle, situated in the Seawater Yard at the Marine Biological Association of the UK. The system consisted of 6 tanks $(28 \times 36 \times 30 \mathrm{~cm})$ filled with ca. $25 \mathrm{l}$ water at 'high tide'. 'High' and 'low tide' were achieved through a system of pumps that allowed tanks to be either filled or emptied simultaneously in about $45 \mathrm{~min}$. Each tank con- tained 5 flat, smooth, large boulders (about 140 to 170 $\mathrm{cm}^{2}$ ), each drilled with two $14 \mathrm{~mm}$ diameter holes to accommodate wax discs to quantify the grazing activity of limpets (see below). The boulders were in contact with each other to allow movements of limpets, while the bottom of the tank was filled with coarse fragments of shells and the sides were covered with a metal mesh to prevent limpets from escaping.

Small cobbles with Patella vulgata (average length $36 \pm 10 \mathrm{~mm}$ ) were collected at the beginning of each experiment from the shore at West Hoe. Relocation of limpets onto the test boulders in experimental tanks was achieved by removing the cobbles once limpets moved from them onto the test boulders. This operation continued until a total of 5 limpets per tank had moved onto the test boulders, which took up to $20 \mathrm{~d}$.

Experiments tested the effects of different amounts and grain sizes of sediment. Amounts of sediment were 50,100 or $200 \mathrm{~g}$ dry wt (50 $\mathrm{g}$ being equivalent to about $2 \mathrm{~g}$ dry wt $\mathrm{l}^{-1}, 50 \mathrm{mg}$ dry $\mathrm{wt} \mathrm{\textrm {cm } ^ { - 2 }}$ and a $1 \mathrm{~mm}$ thick layer; these increased proportionally for 100 and $200 \mathrm{~g}$ ). These amounts mimicked a wide range of sediment deposits likely to occur on rocky coasts close to urban areas (e.g. Airoldi et al. 1996, Connell 2005). Sediment was collected in April 2002 from a tidal flat in the nearby Plym Estuary. Sediment was oven-dried and manually sieved through wire meshes of 500 and $250 \mu \mathrm{m}$ in order to separate a 'coarse' fraction (retained on the $250 \mu \mathrm{m}$ sieve) from a 'fine' fraction (passing through the $250 \mu \mathrm{m}$ sieve). Although the site where sediment was collected is not considered particularly polluted, duplicate samples of each fraction were analyzed for contents of metals and tributyltin (TBT). Triplicate samples of each fraction were also analyzed for grain size distributions by using a laser particle sizer (Malvern Instruments).

It was too difficult to set up enough replicate 'tidal' tanks to simultaneously test the effects of different amounts and grain sizes of sediments in orthogonal combination. Because feeding activity of limpets varies seasonally (e.g. Jenkins et al. 2001), comparison of results from experiments run at different times would have also proved impractical, requiring great temporal replication of the experiments. Therefore, we tested the effects of different combinations of sediment amounts and grain sizes during 6 independent experiments, run from April 2002 to February 2003. In each experiment, 5 new limpets were used per tank. At the beginning of each experiment, treatments (sediment addition vs. unmanipulated control) were each assigned at random to 3 tanks. Responses of Patella vulgata to sediment were quantified as differences in rates of grazing and mortality among treatments. Rates of grazing were estimated by using the method described by Thompson et al. (1997), which relies on 
distinctive radular marks that are left by grazing limpets on the surface of dental wax cast into small discs and placed into pre-formed holes in the rock surface. Ten wax discs were placed in each tank into the pre-formed holes just before sediments were added to the treatment tanks as a fine 'rain'. The behaviour of the limpets was regularly observed during the experiments, which lasted 8 to $12 \mathrm{~d}$. At the end of the experiments the wax discs were retrieved and the health of limpets checked. Wax discs were examined under a binocular microscope. Grazing rate was estimated by counting the number of marks in contact with a transparent grid of 25 dots regularly spaced over the surface of the disc.

Effects of sediment on grazing rates were analyzed separately for each experiment by 2-way ANOVAs, with treatment (sediment addition vs unmanipulated control) as a fixed factor and tank (3 levels) as a random factor nested in treatment. Homogeneity of variance was assessed by Cochran's $C$-test ( $p$ > 0.05).

\section{RESULTS}

\section{Field observations}

On all shores, sediment occurred as scattered patches (several $\mathrm{mm}$ to several $\mathrm{cm}$ thick) of fine to medium sand, either in depressions and crevices or trapped by turf-forming algae. Despite differences in the composition of benthic assemblages both among

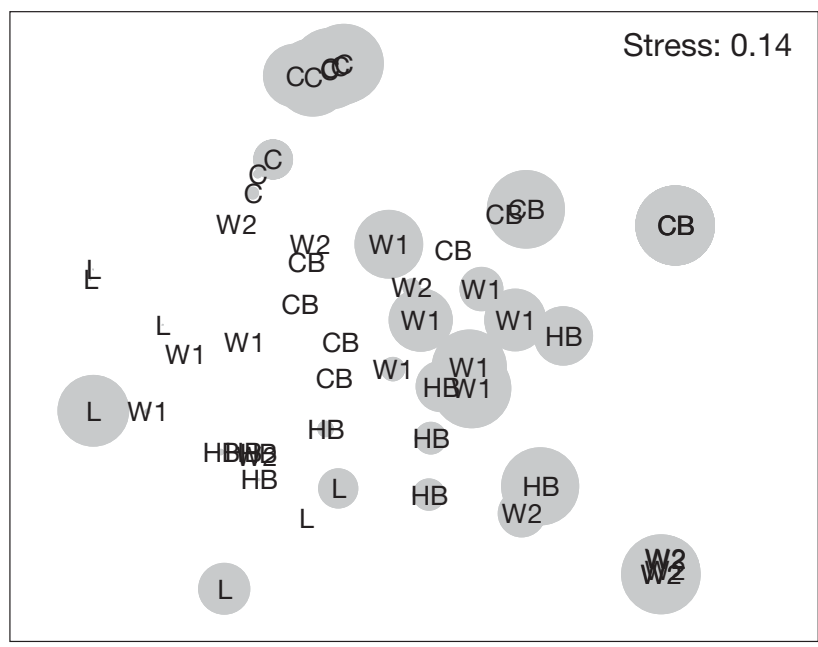

Fig. 1. MDS ordination of 4th root transformed covers of sessile species and density of limpets (mainly Patella vulgata) at the 6 study sites $(\mathrm{L}=$ Looe, $\mathrm{HB}=$ Heybrook Bay, $\mathrm{W} 1$ and $\mathrm{W} 2=$ Wembury 1 and 2, CB = Cawsand Bay, C = Cremyll). Superimposed grey circles represent sediment cover (\%). Points represent 10 plots per site except for $\mathrm{L}$ ( 7 plots) and $\mathrm{CB}$ (9 plots) (4 empty plots were excluded from the analysis)

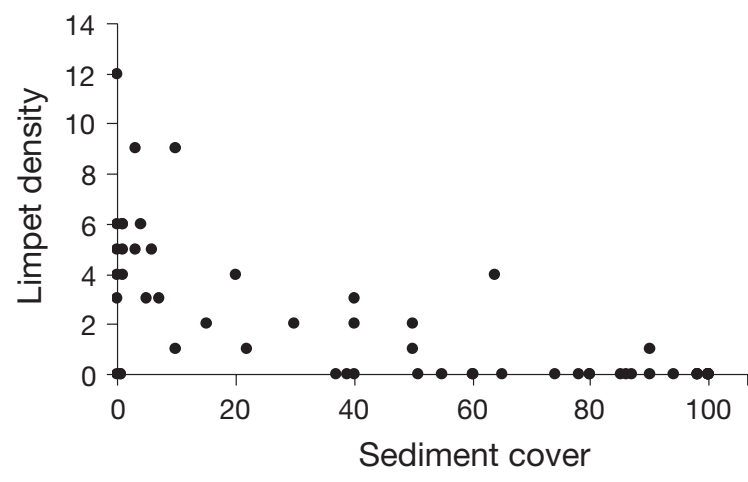

Fig. 2. Patella vulgata. Relationship between limpet density (no. ind. $400 \mathrm{~cm}^{-2}$ ) and sediment cover (\%). Points represent 60 plots (10 from each of 6 sediment-impacted sites)

and between sites, plots with no or low cover of sediments tended to group (Fig. 1) and were characterized by high densities of Patella vulgata and low cover of fleshy macroalgae. Conversely, plots where sediments were present had more heterogeneous distributions of macroalgae and were dominated by either turf-forming algae Fucus vesiculosus or Ulva spp., depending on the shore.

Coverage of sediment and density of Patella vulgata were negatively correlated $(\mathrm{r}=-0.68, \mathrm{p}<0.01)$. Limpets were clearly most abundant in plots with least amounts of sediment, and were locally absent when sediment covered more than 50 to $65 \%$ of the substratum (Fig. 2).

\section{Laboratory experiments}

The particle size distribution and chemical characteristics of the sediments used in experiments are summarized in Table 1. Coarse sediment was dominated by sands $(58 \%)$, whereas fine sediment was dominated by silt $(67 \%)$. The sediments, particularly the fine fraction, contained concentrations of $\mathrm{As}, \mathrm{Ag}$, and $\mathrm{Cu}$ and, to a lesser extent, $\mathrm{Pb}$ and $\mathrm{Zn}$ that exceeded threshold guidelines levels (CCME 1999). Direct, short-term toxic effects were unlikely (W. J. Langston pers. comm.), but such contamination is typical of urban areas where sedimentation is increased by human activities.

In all 6 experiments, rates of grazing were lower in treatments with sediments than in unmanipulated controls (Fig. 3). The effects of additions of fine sediment were always significant, whereas effects of coarse sediment were significant only with the addition of $200 \mathrm{mg}$ $\mathrm{cm}^{-2}$ (but note $\mathrm{p}=0.07$ for 50 and $100 \mathrm{mg} \mathrm{cm}^{-2}$ of coarse sediment, Table 2). Overall, additions of 50, 100 and $200 \mathrm{mg} \mathrm{cm}^{-2}$ of coarse sediment decreased rates of grazing by 35,45 and $50 \%$, respectively (Fig. 3), 
Table 1. Average characteristics of sediment particles used in experiments ( $\mathrm{n}=3$ for grain size distributions, $\mathrm{n}=2$ for metals). Mean, mode, median, sorting, skewness and kurtosis expressed as $\Phi$-values; abundance of sand, silt and clay expressed as \%; abundance of metals expressed as $\mu \mathrm{g} \mathrm{g}^{-1}$ dry wt; TBT (tributyltin) expressed as $\mu \mathrm{g} \mathrm{Sn} \mathrm{g}^{-1}$ dry wt

\begin{tabular}{|c|c|c|c|c|c|c|c|c|c|c|c|c|c|}
\hline Sediment & Mean & \multicolumn{2}{|c|}{ Mode } & Median & \multicolumn{2}{|c|}{ Sorting } & Skewness & \multicolumn{2}{|c|}{ Kurtosis } & Sand & \multicolumn{2}{|c|}{ Silt } & Clay \\
\hline Coarse & 3.09 & \multicolumn{2}{|c|}{1.22} & 2.16 & \multicolumn{2}{|c|}{2.4} & 0.59 & \multicolumn{2}{|c|}{0.79} & 58.07 & \multicolumn{2}{|c|}{38.93} & 3 \\
\hline \multirow[t]{2}{*}{ Fine } & 5.01 & \multicolumn{2}{|c|}{4.68} & 4.91 & \multicolumn{2}{|c|}{1.89} & 0.11 & \multicolumn{2}{|c|}{1.06} & 29.48 & \multicolumn{2}{|c|}{67.12} & 3.4 \\
\hline & $\mathrm{Ag}$ & $\mathrm{Cd}$ & $\mathrm{Co}$ & $\mathrm{Cr}$ & $\mathrm{Cu}$ & $\mathrm{Fe}$ & $\mathrm{Mn}$ & $\mathrm{Ni}$ & $\mathrm{Pb}$ & $\mathrm{Zn}$ & As & $\mathrm{Hg}$ & TBT \\
\hline Coarse & 0.43 & 0.35 & 3.24 & 10.89 & 86.9 & 6.34 & 74.5 & 6.93 & 30.3 & 77.2 & 39 & 0.14 & 0.0014 \\
\hline Fine & 0.82 & 0.58 & 5.26 & 18.32 & 233.3 & 11.56 & 146.4 & 9.4 & 56.5 & 160.3 & 102.7 & 0.34 & 0.0029 \\
\hline
\end{tabular}

Table 2. ANOVA results: effects of combinations of sediment amount and grain size on grazing rate (\% wax disk scraped per day) of limpets. Cochran's $C$-test was always non-significant except under a load of $200 \mathrm{mg} \mathrm{cm}^{-2}$ fine sediment $(C=0.3908, \mathrm{p}<0.05)$. Significant $\mathrm{p}$-values in bold; $\mathrm{T}=$ treatment

\begin{tabular}{|c|c|c|c|c|c|c|c|c|c|c|}
\hline & \multirow[t]{2}{*}{ df } & \multicolumn{3}{|c|}{$50 \mathrm{mg} \mathrm{cm}^{-2}$} & \multicolumn{3}{|c|}{$100 \mathrm{mg} \mathrm{cm}^{-2}$} & \multicolumn{3}{|c|}{$200 \mathrm{mg} \mathrm{cm}^{-2}$} \\
\hline & & MS & $F$ & $\mathrm{p}$ & MS & F & $\mathrm{p}$ & MS & $F$ & $\mathrm{p}$ \\
\hline \multicolumn{11}{|l|}{ Fine } \\
\hline $\mathrm{T}$ & 1 & 192.8 & 9.57 & 0.036 & 374.9 & 110.1 & $<0.001$ & 447.9 & 22.87 & 0.009 \\
\hline Tank (T) & 4 & 20.2 & 1.17 & 0.333 & 3.4 & 0.6 & 0.69 & 19.6 & 4.32 & $\mathbf{0 . 0 0 4}$ \\
\hline Residual & 54 & 17.2 & & & 6.0 & & & 4.5 & & \\
\hline \multicolumn{11}{|l|}{ Coarse } \\
\hline $\mathrm{T}$ & 1 & 154.0 & 5.91 & 0.072 & 124.5 & 5.61 & 0.077 & 262.9 & 10.02 & 0.034 \\
\hline Tank (T) & 4 & 26.0 & 1.69 & 0.164 & 22.2 & 1.93 & 0.118 & 26.2 & 2.83 & 0.034 \\
\hline Residual & 54 & 15.4 & & & 11.5 & & & 9.3 & & \\
\hline
\end{tabular}
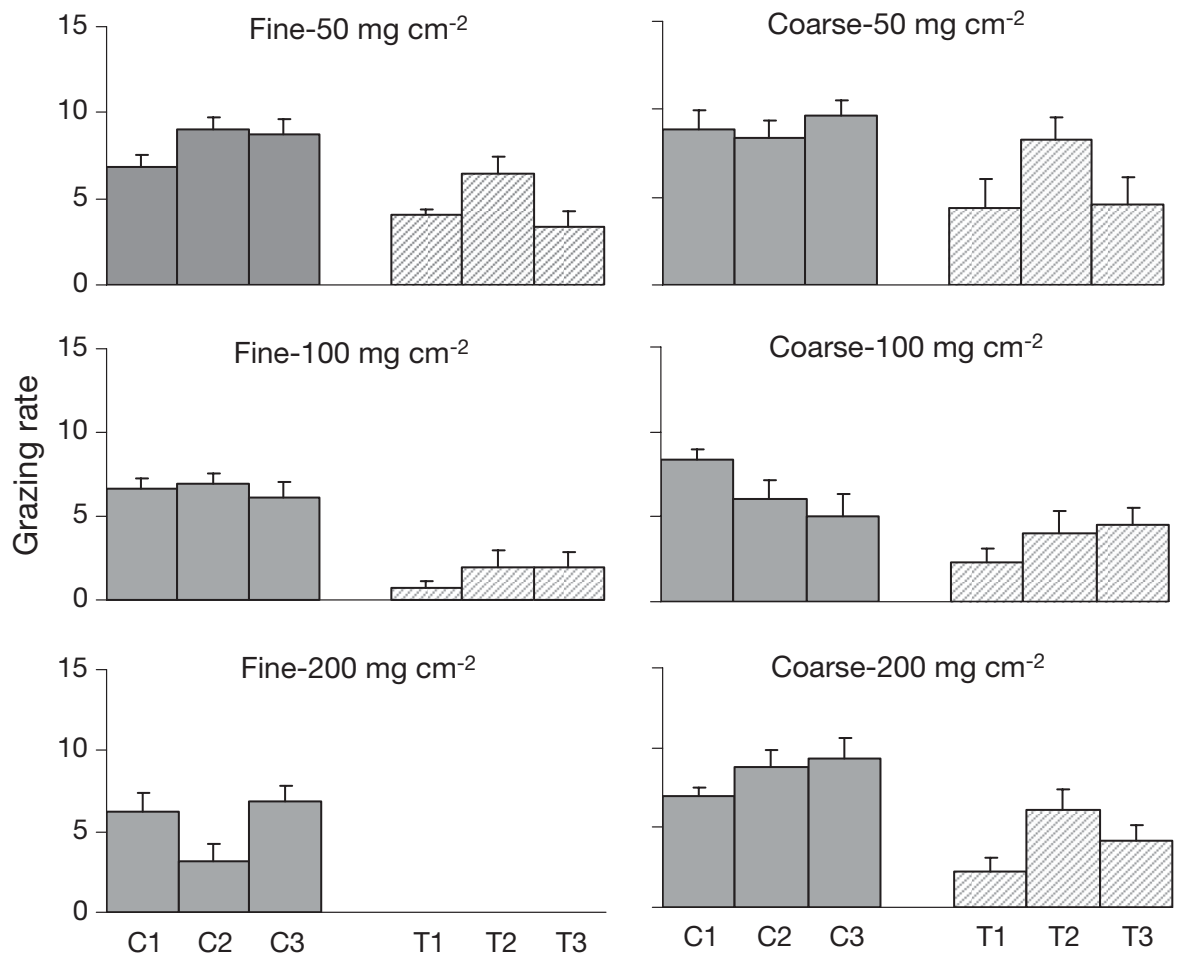

Fig. 3. Patella vulgata. Grazing rate (\% wax disk scraped per day) measured in 3 sediment-addition treatment (T) and 3 unmanipulated control (C) tanks during 6 experiments testing combinations of sediment amount $\left(50,100\right.$ and $\left.200 \mathrm{mg} \mathrm{cm}^{-2}\right)$ and grain size (fine and coarse). Grazing rate was 0 in all treatment tanks containing $200 \mathrm{mg} \mathrm{cm}^{-2}$ fine sediment. Data are mean $\pm 1 \mathrm{SE}$ 
whereas additions of 50 and $100 \mathrm{mg} \mathrm{cm}^{-2}$ of fine sediment decreased rates of grazing by 40 and $77 \%$, respectively (Fig. 3). When $200 \mathrm{mg} \mathrm{cm}^{-2}$ of fine sediment was tested, grazing was totally inhibited (Fig. 3): limpets initially tried to escape sediments but lost attachment after a few days, and subsequent mortality was observed.

\section{DISCUSSION}

We observed that Patella vulgata was generally absent from rocky shores near Plymouth when sediments covered more than $50 \%$ of the rock. This distribution can be accounted for by the low tolerance of $P$. vulgata to sediments. In the laboratory, the grazing activity of $P$. vulgata was severely inhibited by the presence of a sediment layer that was only $\sim 1 \mathrm{~mm}$

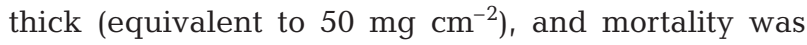
recorded under loads of $200 \mathrm{mg} \mathrm{cm}^{-2}$ fine sediment.

It is possible that the effects of sediments under natural field conditions may be less severe than those observed in our experiments: firstly, because limpets can respond to patchy accumulations of sediments by moving out of disturbed areas; secondly, because laboratory conditions are likely to impose additional stress on organisms; and thirdly, because waves in the field will tend to re-suspend deposited sediments. Nevertheless, it is clear that the presence of sediments per se is an important source of stress for Patella vulgata. Furthermore, a broad spectrum of land- and ocean-based human activities (Airoldi 2003, Ahrens \& Morrisey 2005) is likely to result in large-scale and persistent loads of thin layers of sediments. These layers will resemble those of experimental conditions of the present study, rather than the dynamic and patchy accumulations of sediments in naturally sand-impacted shores, and will negatively affect limpets.

Fine sediments affected Patella vulgata more severely than coarse sediments, particularly when they formed thicker deposits. Indeed, grain size composition greatly influences the effect of sediments (Airoldi 2003), but generalizations are difficult. For example, during a laboratory experiment, fine sediments had more detrimental effects than coarse sediments on the survivorship and growth of embryos of Fucus serratus (Chapman \& Fletcher 2002), which was attributed to higher diffusion barriers. Conversely, during a field experiment, coarse sediments had more negative effects than fine sediments on the biomass of subtidal turf-forming algae (Airoldi \& Virgilio 1998), which was attributed to greater scour. Our experiments simulated water movements related to tidal regimes rather than to wave action, which is a common condition in shel- tered environments. It is possible that effects of coarse sediments would be more significant under more dynamic flow conditions.

A number of studies have shown distinct spatial and temporal variations in the feeding activity of limpets, including Patella vulgata (Thompson et al. 1997, Jenkins \& Hartnoll 2001). Proposed explanations have focussed on the roles of sea temperature, wave action, slope of the rock, reproductive activity and food supply (Della Santina et al. 1994, Jenkins \& Hartnoll 2001, Santini et al. 2004). We showed that even a thin layer of sediment may severely reduce the grazing rate of $P$. vulgata. Thus, spatial and temporal variations in sediment loads could influence the grazing activity of limpets. For example, accumulation of sediments, especially the finest fractions, is in general most pronounced at sheltered locations (Airoldi 2003), which could at least in part explain the differences in grazing activity of $P$. vulgata between exposed and sheltered shores (Jenkins \& Hartnoll 2001).

Future work should attempt to clarify the mechanisms by which sediments impair Patella vulgata. These could include the clogging of gills, thereby reducing oxygen availability and leading to physiological stresses, or interference with attachment, movements or feeding activities, or a combination of these factors. Possible harmful effects resulting from the presence of contaminants should also be considered. Although acute toxic effects were unlikely under the present experimental conditions, contaminants are often present in sediments-especially along urbanized coastlines-and could exert adverse chronic effects on top of those resulting from the particulates themselves (Ahrens \& Morrisey 2005).

Any physical and biological processes affecting the feeding and distribution of limpets will have consequences for the organization of intertidal rocky shore assemblages (Jenkins et al. 2005). We have shown that sediments have direct negative effects on the limpet Patella vulgata: even a thin layer of sediment may impair this species and significantly decrease its grazing activity. Because sediment deposition on rocky shores is a highly dynamic process, it is clear that the effects of sediments will ultimately be related to their spatial and temporal distribution. Indeed, on rocky shores close to Plymouth, the natural patchiness of sediments was related to the distribution of $P$. vulgata and macroalgae, thereby generating spatial heterogeneity. Any change in sedimentation regime that results in a persistent alteration of the characteristics and distribution of sediment particles could, therefore, pose a serious threat to the diversity and function of rocky shore assemblages through the inhibition of grazing by limpets, in addition to direct effects such as smothering or scouring. 
Acknowledgements. This study was supported by a LINKECOL Exchange Grant from the European Science Foundation and an Assegno di Ricerca of Bologna University to L.A., and by a NERC grant-in-aid MBA fellowship to S.J.H. We are grateful to F. Arenas for invaluable assistance with planning and conduction of experiments, J. Rundle and F. Frettsome for setting up the tidal system, W. Langston and P. Moschella for sediment analyses, L. Noel and M. Abbiati for assistance with laboratory and field work, and 2 anonymous reviewers. This publication is contribution number MPS07017 of the EU Network of Excellence MarBEF.

\section{LITERATURE CITED}

Ahrens MJ, Morrisey DJ (2005) Biological effects of unburnt coal in the marine environment. Oceanogr Mar Biol Annu Rev 43:69-122

Airoldi L (2003) The effects of sedimentation on rocky coast assemblages. Oceanogr Mar Biol Annu Rev 41:161-263

Airoldi L, Virgilio M (1998) Responses of turf-forming algae to spatial variations in the deposition of sediments. Mar Ecol Prog Ser 165:271-282

Airoldi L, Fabiano M, Cinelli F (1996) Sediment deposition and movement over a turf assemblage in a shallow rocky coastal area on the Ligurian Sea. Mar Ecol Prog Ser 133: 241-251

Benedetti-Cecchi L, Bulleri F, Acunto S, Cinelli F (2001) Scales of variation in the effects of limpets on rocky shores in the northwest Mediterranean. Mar Ecol Prog Ser 209: 131-141

Branch GM, Eekhout S, Bosman AL (1990) Short-term effects of the 1988 orange river floods on the intertidal rockyshore communities of the open coast. Trans R Soc Afr 47: 331-354

CCME (Canadian Council of Ministers for the Environment) (1999) Canadian environment quality guidelines. Canadian Council of Ministers for the Environment, Winnipeg

Chapman AS, Fletcher RL (2002) Differential effects of sediments on survival and growth of Fucus serratus embryos (Fucales, Phaeophyceae). J Phycol 38:894-903

Clarke KR (1993) Non-parametric multivariate analyses of changes in community structure. Aust J Ecol 18:117-143

Connell SD (2005) Assembly and maintenance of subtidal habitat heterogeneity: synergistic effects of light penetration and sedimentation. Mar Ecol Prog Ser 289:53-61

Della Santina P, Naylor E, Chelazzi G (1994) Long-term field actography to asssess the timing of foraging excursions in the limpet Patella vulgata. J Exp Mar Biol Ecol 178:193-203

Hawkins SJ (1981) The influence of Patella grazing on the fucoid-barnacle mosaic on moderately exposed rocky shores. Kiel Meeresforsch 5:537-543

Hawkins SJ, Hartnoll RG (1983) Grazing of intertidal algae by marine invertebrates. Oceanogr Mar Biol Annu Rev 21:

Editorial responsibility: Otto Kinne (Editor-in-Chief), Oldendorf/Luhe, Germany
$195-282$

Hawkins SJ, Hartnoll RG, Kain JM, Norton TA (1992) Plantanimal interactions on hard substrata in the North-East Atlantic. In: John DM, Hawkins SJ, Price JH (eds) Plantanimal interactions in the marine benthos. Clarendon Press, Oxford, p 1-32

Jenkins SR, Hartnoll RG (2001) Food supply, grazing activity and growth rate in the limpet Patella vulgata L.: a comparison between exposed and sheltered shores. J Exp Mar Biol Ecol 258:123-139

Jenkins SR, Hawkins SJ, Norton TA (1999) Direct and indirect effects of a macroalgal canopy and limpet grazing in structuring a sheltered intertidal community. Mar Ecol Prog Ser 188:81-92

Jenkins SR, Arenas F, Arrontes J, Bussell J and 10 others (2001) European-scale analysis of seasonal variability in limpet grazing activity and microalgal abundance. Mar Ecol Prog Ser 211:193-203

Jenkins SR, Coleman RA, Della Santina P, Hawkins SJ, Burrows MT, Hartnoll RG (2005) Regional scale differences in the determinism of grazing effects in the rocky intertidal. Mar Ecol Prog Ser 287:77-86

Lubchenco J, Gaines SD (1981) A unified approach to marine plant-herbivore interactions. I. Populations and communities. Annu Rev Ecol Syst 12:405-437

Marshall DJ, McQuaid CD (1989) The influence of respiratory responses on the tolerance to sand inundation of the limpets Patella granularis L. (Prosobranchia) and Siphonaria capensis Q. et G. (Pulmonata). J Exp Mar Biol Ecol 128:191-201

Pulfrich A, Parkins CA, Branch GM, Bustamante RH, Velásquez CR (2003) The effects of sediment deposits from Namibian diamond mines on intertidal and subtidal reefs and rock-lobster populations. Aquat Conserv Mar Freshw Ecosyst 13:257-278

Robles C (1982) Disturbance and predation in an assemblage of herbivorous Diptera and algae on rocky shores. Oecologia 54:23-31

Santini G, Thompson RC, Tendi C, Hawkins SJ, Hartnoll RG, Chelazzi G (2004) Intra-specific variability in the temporal organisation of foraging activity in the limpet Patella vulgata. Mar Biol 144:1165-1172

Schiel DR, Wood SA, Dunmore RA, Taylor DI (2006) Sediment on rocky intertidal reefs: effects on early post-settlement stages of habitat-forming seaweeds. J Exp Mar Biol Ecol 331:158-172

Southward AJ (1964) Limpet grazing and the control of vegetation on rocky shores. In: Crisp DJ (ed) Grazing in terrestrial and marine environments. Blackwell Scientific Publications, Oxford, p 265-273

Thompson RC, Johnson LE, Hawkins SJ (1997) A method for spatial and temporal assessment of gastropod grazing intensity in the field: the use of radula scrapes on wax surfaces. J Exp Mar Biol Ecol 218:63-76

Submitted: March 29, 2006; Accepted: July 31, 2006

Proofs received from author(s): February 19, 2007 